\title{
Digteren og Den Sandheds Ånd \\ Grundtvigs helligåndsteologi \\ og den engelske romantik
}

\section{Af Henrik Wigh-Poulsen}

I den nyere Grundtvig-forskning er det blevet sagt, at linjerne i »De levendes Land « om den »strålende hånd, som rækker fra himlen til jorderigs muld «, har deres udspring i en sommerlig skovvision, Grundtvig havde, da han iagttog solens stråler falde gennem løvet. Ligeledes er det af samme forsker (og her tænker jeg selvfølgelig på Chr. Thodberg) blevet slået fast, at der hverken var sne eller klingrende frost den nat, Grundtvig skrev »Velkommen igen..«. Jeg vil, i forlængelse af disse unders $\emptyset$ gelser, forsøge at tematisere min artikel om Grundtvig og Helligånden ved at inddrage endnu et vejrfænomen, nemlig blæsten, vinden, eller som vi hos Grundvig bedst kender den, »den hjemlige viften gennem løvet « og den »liflige luften under sky."

Men nu har vinden det jo med at blæse, hvorhen den vil, så jeg kan desværre ikke rigtigt hægte den på selvbiografiske optegnelser eller historiske prognoser fra Metereologisk Institut. Man ved ikke, hvorfra den kommer, og hvor den farer hen, så jeg må nøjes med at søge den og digteren Grundtvigs personlige mellemværende med den i den tekst, han efterlod sig.

\section{Den milde brise}

Men allerførst lidt om et noget andet blæsevejr, nemlig den friske forårsvind, der løber langs en bjergside et eller andet sted i det nordlige Englands Lake-District, og som får Grundtvigs næsten samtidige digterkollega, William Wordsworth, til at henånde $i$ et $\gg \mathrm{Oh}$, there is blessing in this gentle breeze ${ }^{1}$, hvorefter han begiver sig ud på en spadseretur, der samtidigt skal indlede det selvbiografiske digt, »The Prelude «, med undertitlen »om en digters bevidsthed i vækst «. Digtet er dermed begyndt, hvor det egentligt skulle slutte, nemlig med den afklarede digter, der nu retrospektivt gør rede for den udvikling, der har ført ham frem til kaldet som poet og profet. 
De bærende akkorder i kaldelsesberetningens tema slås an allerede i de første linjer, hvor den føromtalte, velsignede brise møder den vandrende, og som et himlens åndepust mod hans legeme rejser en korresponderende brise $\mathrm{i}$ hans indre. $\mathrm{Al}$ hans indre del sig rører, idet den indre brise bliver til et ustyrligt, skabelsessvangert stormvejr med løfter om poetisk nybrud. Milton lukkede sit »Tabte Paradis « med skildringen af Adam og Eva, der går den byrdefulde gang ud $\mathrm{i}$ verden. Den romantiske poet Wordsworth kan åbne sit digt med at spankulere fortrøstningsfuldt og inspireret samme vej, for han er digteren, skaberen, der formår at lade sin indbildningskrafts, sin imaginations, lys skinne på den faldne verden for at lade den opstå på ny. »Paradiset og de Elysiske Lunde «, hvorfor skulle de blot være historie og opspind, spørger Wordsworth andetsteds sig selv og indirekte Milton, og fortsætter: Paradiset, det findes $\mathrm{i}$ vores hverdag, når blot vi lader vores sansende og skabende bevidsthed, vores imagination, indgå $\mathrm{i}$ et helligt ægteskab med verden omkring os. ${ }^{2}$

Hvad er så Wordsworth's brise? Af hvilken beskaffenhed er dette nordengelske blæsevejr og dets, i den spadserende digter fremkaldte, indre ækvivalent? Ja, den amerikanske litteraturkritiker, M.H. Abrams, mener jo, at den romantiske litteratur i sine begreber, ideer og paradigmer slet og ret er en sækulariseret eller humaniseret oversættelse af et godt gammeldags, traditionelt bibelsk-kristent tankesæt. ${ }^{3}$. Wordsworth's brise må derfor, siger Abrams, læses som stående i en fjern, men direkte familierelation til Helligånden eller den Guds Ånd, der opfyldte profeterne og antændte apostlenes ildtunger; men sådan forstået at den religiøse side af sagen alene overlever som et retorisk ekko eller en sproglig mindelse, en genkendelig ramme til at fylde romantikkens nye og revolutionerende budskab ind i. Tilbage bliver suset fra den magtfulde erindring om Åndens berøring af den udvalgte; men her, i romantikerens prædiken til en ny tid, er det naturens »virkelige «, forårsbebudende brise, der smyger sig om digteren og kalder ham til hidtil usete bedrifter.

Kan være, at Abrams med sin noget enstrengede tese slører og glider uden om de genuint bibelske træk og de klare teologiske ambitioner, der også findes hos Wordsworth, Coleridge og Blake; men han er vældig anvendelig til at fremhæve de om- 
råder, hvor Grundtvig i hvert fald ikke ligner de øvrige romantikere, hvor hans viften klart adskiller sig fra deres brise.

\section{Den åndelige viften}

Det er nemlig en viften, det drejer sig om hos Grundtvig, og en sådan finder man i det, i forhold til »The Preludes « verdensklasse, noget forsagte og nærmest forknytte »Fortaleriim $\ll^{4}$, man kan også kalde det Grundtvigs »prelude«, til digtet »Roskilde-Saga « fra 1814.

Her lyder det indtil videre revet ud af sin sammenhæng:

»Haven, Gud os gav herneden

Grændser op til Herrens Eden

Aandelig det til os vifter

Giennem Sprinkelværkets Rifter,

$\mathrm{Og}$ i Anelsen vi finde

Duft, af det, som er derinde.«

Her har vi den, denne stilfærdige slægtning til blæsevejret. Både før og siden brugt af Grundtvig til at betegne Guds ånds dalen ned over skaberværket. Guds ånd, vel at mærke, og intet andet. Grundtvigs viften er ingen fjern genlyd eller en metafor, der skal naturalisere en ædel forgænger for at gøre den gangbar til nye tider. Nej, i den sagte viften der hører Grundtvig højt og tydeligt bruset fra selve pinsedagen. Det er Den Sandheds Ånd, Guds Helligånd, der ånder på vores dagligdag og omgivelser, så at de kan spejle Guds riges hemmeligheder. Sådan, i denne dalen, der gør det paradisiske hjemligt og nært, formidles Guds sandhed til os faldne mennesker. Gennem vores »Sprinkelværk (som betyder noget lignende »et vakkelvornt stakit«, og som derfor skal betegne menneskets kødelige skrøbelighed) gennem dets »rifter «, eller tremmer, frembæres viftningen til det anelsesfulde sind, ret som en herlig blomsterduft.

Grundtvig fortsætter:

»Fryd dig bævende, o Skjald!

Som dit Kaar er og dit Kald; 
Giennem dig sig skal afbilde, Hvad du saae i Livets Kilde, Giennem dig skal i det Brede Rosenduften sig udsprede, «

Og her er der så alligevel en vis overensstemmelse mellem Grundtvig og kollegerne fra England. Begge parter ser digteren som den særligt begavede og udrustede, der formår at sanse Guds usynlige spor i skaberværket - et Eden herneden - og formidle det i sin poesi. For så vidt kan de også, Grundtvig og de andre, enes om, at der foregår en vis kreativ vekselvirkning mellem en indre og en ydre rørelse, at digteren skal omsætte sit indtryk i udtryk; men hvor romantikeren på enhver måde vil være opmærksom på den indre storm frembragt ved den ydre brise - den opvakte, skabende energi, imaginationen, med hvilken digteren, analogt med Gud, kan skabe nyt omkring sig - dér nægter Grundtvig, at digteren bare, på den måde, kan møve sig ind på skaberaktens førsteparket. Nej, han må pænt overlade pladsen til Den Helligånd, der vifter ham i møde, åbenbarer synet for ham, og når alt således kommer til alt, »ånder ham skjaldskabet på «, som det hedder. Den Helligånd med hvilken Gud overhovedet har indblæst ham røsten, mælet og det ord, han udtrykker sig med, når rosenduften skal udspredes $\mathrm{i}$ det brede.

Indbildningskraften, imaginationen, vil Grundtvig hævde, er således, i dens sande virksomhed, loyalt forbundet med og underordnet Guds Ånd som det anlæg, der nok formår at danne sig oversanselige forestillinger og herigennem gribe naturens og universets genstande som dunkle billeder på en himmelsk sandhed. Men, vel at mærke, der er tale om billeder, hvis betydning Gud har forudskikket i og med sin skabelse. Indbildningskraften er altså ikke, som Grundtvig ser det, skabende - den er ydmygt genkendende. Dens indre syn er forudbestemt til at møde sit eget og genstandens skabende ophav.

Skjalden, Grundtvigs ideal-poet, står derfor ganske passiv i sit kald, ved, om jeg så må sige, at lade Ånden blæse lige igennem i villig modtagelse og uforvansket gengivelse. Det er, på enhver måde, Guds åndes vindbrus, der bærer ham og hans poesi.

Men disse just opridsede væsensforskelligheder mellem viftningen og brisen til trods, der må man sige, at romantikerne og 
Grundtvig grundlæggende tilhører samme stamme, samme fællesskab af forkyndere, nemlig poet-profeterne, de af Ånden bårne og Ånden bevægede, der tyder og henpeger på Guds signatur i deres omgivelser.

Besynderligt nok er denne digternes påberåbelse af profetstatus tildels begrundet $\mathrm{i}$ en ny måde at læse Bibelen på, en gryende litterær-kritisk skole, foregrebet af bl.a. digteren Herder. Man kunne pludselig øjne de nu frisatte bibelske skrifters litterære og poetiske kvaliteter. Og især fokuseringen på den gammeltestamentlige profet som et menneske der gribes af Ånden og frembringer stor poesi, blev til vældig inspiration for det sene 1700tals og den tidlige romantiks æstetiske nyorientering hen imod det uspolerede, det upyntede og det naturlige - den såkaldte »primitivisme «. Her greb man begejstret ideen om den hebræiske profets rene poetiske tale, udsprunget af hans umiddelbare kontakt med skabelsens kilde. Digterne identificerede sig med den profet, som de nu var i øjenhøjde med. Han var som dem en seer, den Ånden talte igennem og begavede med en sansende indsigt i Guds mysterium.

Så vidt også Grundtvig, der ofte talte om, hvordan hebræisk stod grundsproget nærmest; hvordan de ypperste af alle skjalde, jødernes profeter, sang, hvad de så og følte, i inderlige og simple, billedlige udtryk. Så vidt også Grundtvig, der som digter stillede sig under den hebræiske profets vilkår og kald som en åndsfortrolig seer, som en inspirationens vindblæste eksistens og, ikke mindst, som den i offentligheden revsende og domfældende autoritet.

Wordsworth's »The Prelude« er i sin helhed henvendt til den nære ven og kollega Samuel Taylor Coleridge som en »auditor in absentia«. Efter at han har bevæget sig igennem størsteparten af sit digt, gennem skildringer af barndom, modning, kriser og sammenbrud, frem til den helende erkendelse af at være en kaldet, da kan Wordsworth, akkurat som da han indledningsvis hilste den frugtbargørende brise velkommen, hilse denne sin ven som en medprofet, og henvendt, ikke alene til ham, men til hele sin samtid, proklamerer Wordsworth i digtets sidste strofer, at som han selv og Coleridge, vil alle poeter, sammenknyttet i et vældigt broderskab, fremstå som profeter, der i naturen evner at sanse det usete og belære verden derom. ${ }^{5}$ 
Grundtvigs ligeledes præluderende »Fortaleriim« er i sin helhed og fra første linje af også henvendt til kollegerne: »Skjalde i den usle Døgn!«, skriver han, og som den adresserende tiltale antyder, så er der i dette tilfælde langtfra tale om triumferende omfavnelser eller begejstrede fællesproklamationer. Tværtimod, Grundtvigs digt er nemlig, siger han selv, et »Feidebrev«. »Jeg om Skjaldskab høit vil tale/Sendt fra høie Kirkesvale«, og det gør han så, ganske højt og formanende. »Skjalde, Skjalde!«, lyder det, husk på, hvad I er sat til. Husk på, at Herren har sat jer i sin urtegård, blandt sine blomster, "For at se med klaret $\varnothing_{\text {ie }} \mathrm{i}$ dem Glandsen fra det høie« - så hold inde med jeres løgn, jeres vellydende falsknerier, der kun vil forvirre og forføre de følsomme sind.

Som profet, som den der er på Åndens parti og derfor har det myndige overblik fra »kirkesvalen «, der kan Grundtvig, som han har gjort det så mange gange før, skælde ud og rydde op på parnasset. Som oftest var det gået ud over den bedagede 1700tals poetik og, hvad han så som dens fint malede, tilpassede fuldkommenhed; men også andre digtere, bl.a. den samtidige Oehlenschläger, fik ved flere lejligheder kærligheden at føle.

Grundtvigs kritik kunne være både perfid og velplaceret; men meget ofte $\mathrm{i}$ de tidlige år, og $\mathrm{i}$ hvert fald her $\mathrm{i}$ fortalerimet, bunder den $\mathrm{i}$ det såre enkle forhold, at digterne ikke har den kristentro, der er forudsætningen for at sanse og viderebringe Guds sandhed. De hænger hovmodigt fast i kødet og forråder Ånden - kort sagt.

Og så står han der, profeten, der bringer bud fra Ånden, og sparker ud efter sine samtidige, hvor en anden romantiker hellere vil tale om broderskab og fælles gang ind $i$ en ny tid. Grundtvig virker i sagens natur ensom i sit kald. Isoleret, som han jo i grunden er, i eksklusivt selskab med Den Sandheds Ånd.

\section{»(...) min egen Andeluft«}

Men så er det, at han midt i denne ånds-opblæste skråsikkerhed afbryder den belærende og formanende tiltale for pludseligt at knække over i følgende passage: 
»Blommer ved Guds Rosenkilde

I, hvis Lignelse jeg vilde,

Som jeg saae den, her afbilde.

I, hvis Duft mig blev tilviftet,

Og igiennem mig udskiftet!

$\mathrm{Ak}$, den klare Himmelfarve

Kunde ei mit Billed arve,

Og min egen Aandeluft

Blanded sig med Eders Duft! «

Hvad er nu det? Hvorfor denne knagen i en ellers vandtæt visionspoetik? Hvorfra denne modvind der forstyrrer den tilviftede blomsterduft - Åndens uhindrede gennemtræk? Grundtvig selv kalder den for sin egen »Aandeluft.«

Er det, spørger jeg så, en indbildningskraftens indre brise, der alligevel og på trods af alle forholdsregler har forladt sin tilbagetrukne, receptive, genkendende og åbenbaringsformidlende funktion for at ville sit eget og blive et selvavlende blæsevejr, ganske som Wordsworth's?

Grundtvig er sårbar i sin elysiske ensomhed, og han frygter af gode grunde indbildningens kraft. Han har lukket den ind i sin poetik og sin teologi, selvfølgelig underlagt Åndens overherredømme; men han er også med sin protestantiske kristentro klar over de farer, det bringer med sig.

F. eks. i »Dannevirke«-afhandlingen fra 1817 om »Aabenbaring, Konst og Vidskab « ${ }^{6}$ : Det er indbildningskraften alene, der kan fragte den åbenbaring, vi modtager; det står fast; men, erkender han, man taler om, at åbenbaringen således bliver et ".vildt Lystspil, og et tomt Hjernespind, som kun avlede en Mystik og Poesie, der netop var det modsatte af Sandhed. « ${ }^{7}$ Grundtvig giver her mæle til en klassisk, reformert mistænksomhed overfor indbildningskraften, udsprunget af frygten for dens afgudsskabende potentiale. Indbildningskraften vil sit eget, lyder sådan en argụmentation. Indbildningskraften er båret af et begær efter verden, som vi ønsker at se den, og derfor vil den med sine fiktioner afsondre os fra Guds virkelighed, verden som den i sandhed er. Den kan være en fæl usurpator, der vil fortrænge visionens umiddelbare og virkelige Ånds-nærværelse for at sætte sit eget luftcastel, sit eget tankespind, i stedet. 
Grundtvig er altså tvunget til med sin kristnede, romantiske visions-æstetik og det dermed følgende, og på alle måder ophøjede og isolerede, profetkald, indirekte at stille sig selv et fundamentalt men såre prekært spørgsmål: »Taler jeg på egne vegne - og ikke Åndens? Er den ydre viften på trods af alt blot min egen indre brise? « Et spørgsmål som de »verdslige« romantikere i deres påberåbte profetiske fællesskab kunne stille $\mathrm{i}$ en mere betryggende ramme og uden nødvendigvis at se sig på kollisionskurs med Den Sandheds Ånd. Men alligevel: »Er jeg en inspireret profet, eller er det bare lille mig, der har fået en fiks idé? Er jeg født for sent, ind i profetisk eksil fra inspirationens ubetvivlelige nærvær?«

Velvidende at de ikke har nogen garanti for ægtheden af deres visioner, bliver både Grundtvig og hans med-romantikere nødt til at overbevise sig selv og andre om, at visionerne faktisk er ægte, og at de som profeter har et budskab, hvis autoritet ikke bunder i dem selv og deres indbildning alene. Det gør de så ved på forskellig vis at besvare spørgsmålet: hvad er det i grunden at være inspireret og et redskab for Ånden? Hvordan bevise $\operatorname{det}$ ?

Wordsworth skriver og skriver om sin barndom, og om hvordan han her levede i en ekstatisk, umiddelbar naturrus, båret af den uimodståelige blæst fra det allestedsnærværende jordiske paradis. Grundtvig, derimod, for nu at blive i »Dannevirke «afhandlingen, taler længe om, at åbenbaringen af Guds sandhed, »tilviftningen«, kan vise sig som et uforkasteligt vidnesbyrd på trods af den bedrageriske indbildningskraft. Forudsætningen for åbenbaringens annammelse er, at man tilintetgør enhver ond vilje, at man kender sig selv som et faldent menneske og at man ophører med at insistere på sin »jeghed«. Kendetegnene på den af Sandhedens Ånd indskudte åbenbaring er, at den modsiger den kødelige fornuft og fremstår som et dunkelt gådebillede. Ydermere opremses tre virkninger af dens indfindelse: »henrykkelse«, når synerne modtages, »henrivelse«, når de udtrykkes i en strøm af ord, og »oplysning«, når de begribes i sandhed. ${ }^{8}$

Grundtvig vil altså trænge bag om indbildningskraftens måske usande eller modsigende forestillinger gennem en art selv-fortrængningsproces, hvor jegets onde vilje udtømmes og åbenbaringen mødes, uklart og modstræbende af det kødelige menneske 
- frem til det punkt hvor den kristne poet-profet må give efter for Ånden og forkynde det, der toner dunkelt, ja, endog modbydeligt, for verden. Når åbenbaringen således får lov til at virke, beviser den sig selv, slår Grundtvig fast. ${ }^{9}$

Den her anførte strategi kan så læses i »Fortaleriim«et, hvor den sætter ind umiddelbart efter Grundtvigs pludselige mistanke om hans »åndelufts « forplumring af synet. » $\mathrm{Ak}$, jeg er en syndig Mand «, udbryder han, sukker og stirrer, som han jo af og til gør det - og ganske som han har opfordret den ugudelige digter til, knæler og bæver han. Ydmygt lægger han sin rim- og sagastav overkors og finder så fortrøstning $\mathrm{i}$, at i sønderknuselsen, der vil han føle Guds Ånd sænke sig over ham og spiret fra det høje røre hans øje:

$\gg$ Rør med Spiret fra det Høie

Naadefuld det fromme Øie,

Saa det skuer Blomst og Billed,

Som mig Du dem forestilled,

Saa det fromme Hjerte maa

I min Sang kun Dig forstå.«

Den reformert-protestantiske utryghed ved den syndige indbildningskraft og alle dens fiktioner $\mathrm{i}$ alliance med en luthersk nådeslære, har bragt digteren vished om, at han nu, hjælpeløs, fortvivlet og afmægtig, opfyldes af Guds frie given, af Guds neddalende Ånd. Hans egen løse tale er ophørt, og hans angrende tavshed afløst af inspirationens henrykkelse, henrivelse og oplysning. Den meget talendes nervøsitet for løgn, løsagtighed og fantasi er afløst af en tavshed, hvorudfra den sande tale lyder og Ånden vifter uforstyrret:

»Lad din Duft i Kirkehaven

Vifte over Rosengraven!

Størk og trøst og glæd de Fromme!

Kundgiør Verden Herrens Domme!

Jeg maa vandre, jeg maa ile

Har i Verden ingen Hvile,

Jeg maa færdes, jeg maa stride,

Medens Timerne henskride; « 
Som Wordsworth finder Grundtvig nu en åben og banet vej, ad hvilken han iler ud i verden, for, med Åndens luftige tyngde i sit ord, at forkynde, hvad han har skuet.

\section{»(..) Vinter-Storm og Regn«}

Men verden forstår ham jo ikke.

Folk havde svært ved at forstå, hvad Grundtvig skrev, og de havde selvfølgelig deres vanskeligheder med at acceptere, hvad de berettiget anså som hans voldsomme selvovervurdering. $\mathrm{Og}$ det er jo i grunden ikke særlig rart for en profet med anlæg for selvransagelse.

Selv ville han sige, at en profet nødvendigvis må misforstås af sin samtid, og at hans tale nødvendigvis må fremstå som gådefuld. Mennesket er som følge af syndefaldet blevet fremmed for Guds sandhed. For at løse gåden og acceptere profetens tale må gådegætteren derfor bære den rette kristne tro og livsforståelse.

Men enhver Grundtvig-læser vil vide, at et digt af Grundtvig fra den periode kan være et frustrerende og irriterende forhindringsløb, hvor man uafladeligt vil snuble over komplicerede gåder og mytologiske billeder, sammenvævet $\mathrm{i}$ et net af subtile og udspekulerede krydshenvisninger, der truer selv den tålmodige læser med kvælningsdøden i et veritabelt hængedynd af nordiskkristelige sammenstykninger. Er de billeder andet end Grundtvigs egne selvskabte fiktioner, gådelege og esoteriske påhit? Er tomheden og tavsheden efter hans egen tales ophør ikke blot fyldt op af indbildningskraftens nye billeder, der fortfarende flimrer løs i en ubrudt strøm? Dén nagende uvished må Grundtvig skrive sig igennem nogle gange endnu. Han må konfrontere sig selv med tvivlen, igen insistere på sin ydmyge bod, »knæle dybt i sit ler«, og vente på hånden, der rækker fra sky for at klare hans $\varnothing j \mathrm{je}$ og løse hans tunge. For først da kan han med eftertryk sige: »min tale er sand Guds tale. Ånden blæser skam i mit budskab. Det er med rette, at jeg kan betragte mig selv, min egen person, som bærende på en ny tids gennembrud.«

Men lad mig endnu en gang, inden jeg igen tager førergreb på Grundtvig og bevæger mig nogle år frem i tiden, igen for en kort bemærkning konfrontere ham med kollegaen i Nordengland, 
der på sin vis også har lidt skyldfølelse overfor virkeligheden, for når Wordsworth $\mathrm{i}$ sin »Prelude « henvender sig til den tavst lyttende ven, så er det, fordi han ved at dække sig ind under en offentlig henvendt adressering søger at undvige det private eller strengt subjektive i de syn og visioner, han kundgør. Forkyndelsen, der lyder til Coleridge, og igennem ham til verden, synes at forlene det af Wordsworth alene erfarede med en vis kommunikerbar almengyldighed og accept.

I digtet »Påske-Liljen « fra $1817^{10}$ høres Grundtvig også pludselig tale $i$ anden person ental og til sidst første flertal. I en af de afsluttende strofer møder vi ham endog i en trefoldig omfavnelse. Aldeles ikke med kollegerne; men, som der står: "Saga!, kom da, lad os sjunge!/Trykke Liljen ømt til Bryst!/At du og har Fugle-Tunge,/Høre Verden i min Røst!«

Men først påskeliljen, den entydigt voksende forårsblomst i den vintermørke landsbyhave, det rummelige tegn for digteren selv, hans poesi og Kristi opstandelse. Påskeliljen står derude midt i uforstandens »vinterstorm og regn «, viftningens kvælende modsætning. Grundtvig kunne allerede her resignere i et: »Ved mit Syn kun den sig fryder,/ Som har kiær, hvad jeg Betyder.« Og så alligevel og igen denne tvivl: »Bondeblomst; men er det sandt! Har vi noget at betyde! « Grundtvig lader ikke i første omgang tvivlen være rettet imod sin egen tale; men den prædiken han selv, hans digtning og blomsten står inde for, og som betinger deres eksistens. Er den tant? Noget vi bare finder på? Er livet virkelig stærkere end døden? Stod han op, som ordet går?

Fortvivlelsen og sukket, angsten for på den måde at være henvist til visnen og glemsel, afløses så af visionen, den stærke dråbe, der vækker troen, digterevnen og visheden om synet af de døde »I en Paaske-Morgen-Røde «. Men igen trænger spørgsmålet sig på, og denne gang går det udelukkende på karakteren af det afgørende og aldeles subjektive syn! Er det noget jeg bilder mig ind? »Sværmer jeg!« Og så føres »Saga«, historiesymbolet, ind på scenen. Grundtvig er ikke alene. Den ahistoriske og oprindelsesløse indbildningskraft, tavst og truende lurende i kulissen, kan nu påhægtes historien - denne for Grundtvig at se objektive, almengyldige og faktiske størrelse, i hvis tjeneste 
indbildningskraften kan spejle Guds sandhed, formidle hans åbenbaring og på den måde undgå det selvgjorte.

Derfor kan Grundtvig triumfere: »Sværmer jeg! ja, sværmer du,/Saga!« Grundtvig føler sig ikke alene, og i Sagas selskab svæver han nu over tidens hav til den lukkede grav, hvor de begge sætter sig til rette ved klippens fod for at iagttage det opstandelsesdrama, der efterfølgende gengives i mysteriespillets form. »Saga!, ja, jeg saae det grandt,/ Herlig stod han op af Døde, « kan han herefter udbryde; m.a.o. jeg, eller som han nu til sin store lettelse kan sige, "vi« har altså noget at betyde. Ganske som Ånden har Saga rørt hans øje og lånt ham tunge. Som Lundgren-Nielsen, hvis analyse af »Paaske-Liljen« jeg i hovedsagen har gjort brug af i det ovenstående, skriver, så kan Grundtvig nu, »..med historiens hjælp, fastholde, forme og karakterisere de sværmeriske syner, så fortiden vågner 'i livsaligt Minde'." "I Ikke Ånden alene, for det kan enhver i grunden hævde, men nu også Saga har denne gang lånt den isolerede digter, »Paaske-Liljen«, sin autoritet, som den der formår at pege på en oprindelse, et urokkeligt udgangspunkt. Således forenet med Saga og den forårsbebudende blomst begejstres Grundtvig over det jubelår, han har i vente som en dansk profet, en levendegører af fælles fortid - den der kalder til nye bedrifter, »tegnet «, med egne ord, »For en Blomster-Tid i Norden.« Med forvisningen om et snarligt gennembrud kan Grundtvig så uantastet, stadigvæk i »Vinter-Storm og Hagl og Regn«, gentage sit »Ligegodt, naar den sig fryder,/Som har kiær, hvad jeg betyder! «, for i grunden er intet ændret; men han har dog, denne gang med Sagas hjælp, skrevet sig frem til visheden een gang til.

Og så alligevel; igen, da den trodsige begejstring har lagt sig, er han ladt alene tilbage i den ophøjede, forblæste ensomhed, hvor »Åndeluftens « hovmod og hjernespind er en stadigt nagende mulighed. Hvor er de, der ved, hvad han betyder? En profet er jo afhængig af en normerende tradition, en menighed, en kirke, der kan sige: »Den er god nok. Han taler Åndens sprog. Han er en i sandhed inspireret.«Uden den er han henvist til at bære en tvivlens og uvishedens byrde, hjemsøgt af en rastløs trang til vished om sin egen tales ægthed og plaget af angsten for den ensomme galskab. 
»Stormen sused, vandløb kom,/styrted dog ej huset om»

Grundtvig mangler en kirke, og sandelig, fra omkring 1821, hvor han kommer i embede, begynder han at ane konturerne af en d.v.s han begynder nu at betragte kirken som en historisk størrelse. Langsomt går det op for ham på mageløs vis, at Ånden stadigvæk gør levende i Herrens menighed. Nu hører han den kalde til opvækkelse og nye bedrifter - så faktisk er den der, kirken, uagtet hans bekymringer og kampe. En særdeles virkelig størrelse. En ubrudt kæde gennem tiderne, sammenknyttet ved dåben og nadveren. Et givet historisk fællesskab. Et rum, hvori Ånden kan virke, og hvor Grundtvig befinder sig som præst og døbt sammen med Herrens menighed til alle tider.

Grundtvig skriver så endnu en præluderende fortale. Fortalen til »Nyaars-Morgen « fra $1824 .{ }^{12}$ »Det er vistnok ikke rimeligt, at dette Riim vil tækkes mange«, erkender han i denne første linje. Men alligevel kan han tale om nogle af sine »Riim-Stavs gamle Venner « og ligefrem udtrykke håb om nye læsere, der vil finde sig i hans tales dunkelhed. For meget er sket med denne seer. En tanke har gennemlynet ham, at »Natten var forgangen, og Dagen kommet nær.« Han har, som sædvanlig på forkant med det nyes gennembrud, erhvervet et nyt og lysende håb om en vækkelse i Danmark og Norden. Han vil stræbe efter en oplivelse af »Nordens Helteånd. "Saga, historiens vingesus, der fik styr på hans sværmeri, får ham til at vende sig mod fædrene, og han vil nu høste, hvad de såede af åndelig rigdom. »Døden skal aldrig faa bugt med Herrens menighed «, skriver han, og i spidsen for den påståede lille kreds, der stoler på Herren, kan han kalde det »Et skrig mod Aanden «, hvis hans opdagelse stemples som sværmeri. Grundtvig smøger ærmerne op. Nu skal der ske noget. Krønniker skal skrives, og salmer skal fornys og formeres. Det virker, som om Grundtvig fryder sig over endelig at være kommet i kontakt med noget »virkeligt «, et fundament og et både historisk og nutidigt fællesskab, hvorudfra han kan lade sit digter- og profetkald virke til oplysning i Åndens ubetvivlelige tjeneste, og hvor de af vinterstormene fremkaldte spekulationer om åndeluft og sværmeri, ikke kan nå ham.

Skænderiet med Clausen i 1825, hvor den her mageløse opdagelse måske først for alvor går op for Grundtvig, giver ham 
lejlighed til at karakterisere kirken, d.v.s. den kirkelige grund, han mener at have fundet, som en »Kiendsgerning«, en »Erfaring «, et »historisk Faktum«, et »Fundament « og en »virkelig« kirke. Clausen, derimod, fremturer med »luftige Indbildninger «, en kirke er er et «Luft-Castel«, »en Tanke-Skygge« og et »Afguds-Tempel. $\ll^{13}$ Ordvalget bringer mindelser om Grundtvigs udfald mod de digtere, der vil deres eget og ikke Guds. Der er en snert af en imaginations-fjendsk, ikonoklastisk retorik i disse gloser. Grundtvig distancerer sig håndfast fra det selvgjorte og fiktionernes besmittelse.

Grundtvig haler så også sin lavmælte ven Ingemann i marken i kampen for kirkens genopvækkelse. Ingemanns »HøjmesseSalmer« fra 1825 ser han nemlig som tegn på en snarlig påskedagning. ${ }^{14}$ Deres særlige kvalitet finder han i den ydmyge bodstone og vemodige inderlighed, deres dybe, stjerneklare vinterhimmel modsat af, hvad man ellers er vant til at se af »..de dejligste Theater-Malerier af vor Gøgle-Verden i konstig Belysning. "Grundtvig skriver i et udkast til en anmeldelse: ${ }^{15}$

„På kirkens vegne være Skjalden (Ingemann) inderlig
takket og velsignet, fordi han som en ægte Arons Søn, ej
ville bære fremmed Ild til Herrens Alter, ei reise noget
støbt eller udskaaret Billede i Helligdommen, ei krandse sig
til Høitider som til en Bacchus-Fest med vellyst duftende
Blomster, men vilde heller knæle som en fattig Pilegrim
ved Herrens Grav, bade sig bodfærdig i Jordans Flod, og
med en hellig Taare i Øiet, støttet paa den nøgne Pal-
megren, henstirre paa Gruset af Herrens sjunkne Tempel.«

Sådan! Ingen hovmodig skabertrang her. Bod og selvfornægtelse. Grundtvig har selv kendt disse øjeblikke, hvor hånden snart vil række fra himlen og signe ham med Åndens tale. Men hvorfor har han nu skubbet Ingemann foran sig? Og hvorfor har han egentlig så travlt med i samme anmeldelse, at Oehlenschläger skal ofre sin digtergave på højaltret og blive udødelig med Kristi kirke? Måske nok fordi han igen, ganske som han plejer, er blevet ramt af den mistanke, at han står alene med et syn. Et syn uden substans. En kirkevækkelse uden andre medvirkende end ham selv. 
I en anmeldelse af Fengers udgave af Kingos »Psalmer og Aandelige Sange fra 1828 « $^{16}$ taler Grundtvig fattet om, hvordan den moderne digters selvstændige kunst og subjektivitet distancerer ham fra salmens grundtone og fædrenes store, uovertrufne poesi, deres liv og ånd. Når han ikke selv rigtigt vil gribe pennen og om- og nyskrive nævneværdigt mange salmer, på trods af sin store virkelyst og erklærede trang dertil - er det så ikke, fordi han er bange for igen at finde sig selv overladt til sit eget alt for velkendte selskab? Vil hans personlige, isolerede indgreb her $\mathrm{i}$ påskedagningen ikke let blive den selvstændige digters overgreb? Vil hans virkelige kirke ikke bare fordampe som et andet luftcastel? ${ }^{17}$

Måtte Ånden dog snart rejse den kirke, ikke kun som en konkret, historisk klippegrund; men, vel at mærke, også som en virkelig og levende menighed!

"Det volder alt den And, som daler.."

I 1837 kommer så »Sang-Værk til den Danske Kirke «, og det indledes med et redigeret sammendrag af »Nyaars-Morgen « fra $1823{ }^{18}$ I denne forkortede version dominerer Grundtvigs samtale med Ånden - en trøstende, tugtende og belærende samtale, der dog til sidst udarter $\mathrm{i}$ et slagsmål, et veritabelt håndgemæng mellem digteren og Helligånden i skikkelse af en due. Nu har Grundtvig åbenbart fået nok. Denne gang venter han ikke tålmodigt på den himmelske belønning; nej, han griber fat i duens vinge, fremfører sin klage over samtidens spot, angrer sit selvbedrag, bedyrer sin ydmyge vilje til et fortsat virke og aftvinger derved til sidst Ånden velsignelsen. »Velan! du har vundet, « erkender den, men »Gak ud og tie stille for Gud!« Hold inde med din evindelige snak og behold den fjer, du har revet ud af min vinge i kampens hede. »Naar Fieren mon klinge,/Jeg gav sig til Pen,/Da rører min Vinge/Den savnede Ven.« Grundtvig vinder Helligåndens mæle og kan nu, 14 år senere, præsentere det, han ser som resultatet af sin slåskamp: Det monumentale sangværk med det universelle vingefang. Den kirkelige anskuelses frugt. De syv historiske folkemenigheders lovsang, "samlet og lempet« og skabt af N.F.S. Grundtvig. Generøst rækker han 
Sangværket frem til en tilhørerskare, en menighed og en kirke, som nu faktisk er der. Pludselig er de begyndt at komme til syne, lyttende og syngende. Grundtvig kan træde ind i deres fællesskab. Han behøver ikke længere at længes efter fædrenes og Kingos dage, hvor man, som han siger det i en tidligere prædiken, "med brændende Hjerte sang, hvad man saa og følte. $~^{19}$ Nej, han kan nu, i sin påskeprædiken fra $1836,{ }^{20}$ opfordre til poetisk selvtægt. Til at gribe fjeren og udfordre de gamle til kappestrid og så ellers skrive dem sønder og sammen med masser af nye salmer til følge. Det er nu, det gælder. Nu og her!

Grundtvig raver ikke længere rundt i en poetisk privatsfære, $\mathrm{i}$ grublerier og ensom skyggeboksning, kun afbrudt af enkeltstående mesterlige gennembrud, hvor han for et øjeblik formår at skrive Åndens fred og forvisning ned over sit værk. Ud af sin menighed og kirke kan han nu række den ene bedrift efter den anden. Uanklaget - for som han prædiker på pinsedagen, også i $1836^{21}$ : »Kirkens hus .. har udholdt verdens mangfoldige storme.« Den er jo »..indviet (...) af lyden af et vindstød stærkere end stormene fra alle verdens fire hjørner.« De kan spotte os, som de spottede apostlene og sige, ».. at vi er fulde af sød vin.« Men lige som vore fædres salmer ikke var »..vind fra præstelæber og tomt mundsvejr « så lyder vores prædiken og sang »..levende og kraftig på modersmålet «, så at der »..ingen kendelig forskel « er på pinsen da og den, vi fejrer her i dag ved »ØreSund.«

Ånden er kommet til Grundtvig og kirken. Sådan føler han det, og den levende og virkelige menighed modsiger ham ikke. Ud af dette Ånds-overskud kan han skabe og lade sin indre brise flagre, idet han, om jeg så må sige, frejdigt blæser på enhver mistanke om illoyal åndeluft og indbildsk sværmeri.

Wordsworth spadserer, som sagt, derudad med brisen i ryggen, rede til at nyskabe den verden, der ligger åben foran ham. Brisen er en velsignet brise, der lader inspirationen falde over ham. Men den indre energi vokser sig ustyrlig og stærk - som et utøjleligt stormvejr. Den ligner en poetisk kraft, der følger sit eget, uafhængigt af naturen, virkeligheden og den milde brise hvorfra den så end kommer. Faktisk blev Wordsworth's videre spadseretur noget tøvende. Han blev, som Grundtvig, måske nok 
lidt usikker på, om det var vinden eller hans egen alt for personlige indbildningskraft, der bar ham fremad.

$\mathrm{Nu}$ er Grundtvig hinsides den slags bekymringer. Han bevæger sig ubesværet rundt her i sit livs pinse som en sjældent fuldvoksen romantiker, en hjemkommen til virkeligheden, menigheden og det ubesværede modersmål. Han har i kirkens ly kæmpet sig frem til Åndens livgivende magt. Han har givet sig hen i dens bevægende vindstød fra himmel til jord og erkendt den som den luftbårne ord- og skaberkraft, profeterne talte om - og nu formidler han den så ud af sit uden forbehold skabende indre som et dybt livgivende åndedrag, et åndesus $\mathrm{i}$ herrens syngende menighed. Lad mig afslutte med at citere Grundtvig, som vi bedst kender ham. Ikke det usikre »sprinkelværk « fra 1814, men den højt råbende poet-profet, der ikke lader nogen tvivl tilbage om, at her i hans skærsommer, der »ånder « det »himmelsk over støvet,/det vifter hjemlig gennem løvet,/det lufter liflig under sky/fra Paradis opladt på ny. «22

Artiklen er en let revideret udgave af et foredrag holdt på Fyns Stiftskonvent, september 1990.

Noter

1 William Wordsworth, "The Prelude«, Bog 1, Vers 1, 1805, Norton Books 1979.

2 William Wordsworth, »Preface« til »The Excursion«, 1814, »Poetical Works«, Oxford 1984.

3 M.H. Abrams, "Natural Supernaturalism - Tradition and Revolution in Romantic Literature«, New York 1971.

4 „Fortaleriim«, »Værker i Udvalg« (VU), udg. Hal Koch og Georg Christensen, København 1941, bd. 7, pp. 202-11. 
5 »The Prelude«, bog 13, 11. 446-49.

6 „Dannevirke et Tids-Skrift«, København 1817, bd. 3, pp. 201-99.

7 Ibid. pp. 237-38.

8 Ibid. pp. $279-80$.

9 Ibid. p. 249.

10 VU, pp. 289-313.

11 Flemming Lundgreen-Nielsen, „Det handlende ord«, København 1980, bd. 2, p. 725 .

12 »Fortale«, VU, bd. 7, pp. 366-75.

13 „Kirkens Gienmæle « mod Professor Theologiæ Dr H.N. Clausen, VU, bd. 2, pp. 317-49.

14 Grundtvigs anmeldelse af »Høimesse-Psalmer til Kirkeaarets Helligdage af B.S. Ingemann «, »Theologisk Maanedsskrift 1825«, pp. 156-62.

15 Optrykt i »Hymnologiske Meddelelser«, 1983/12.

16 Grundtvigs anmeldelse af „Psalmer og Aandelige Sange af Thomas Kingo«, samlede og udgivne af P.A. Fenger, Præst. (Kjøbenhavn 1827), »Theologisk Maanedsskrift $1828 \ll$, pp. 1-37.

17 Se min artikel »Grundtvig, kunsten og naturen«, »Fønix«, 1989/3, pp. 172184.

18 „For-Spil« (af Nyaars-Morgen 1824), „Sangværk til Den Danske Kirke«, København 1944, bd. 1, pp. 13-32.

19 N.F.S. Grundtvigs Prædikener, udg. Christian Thodberg, København 1983, bd.2, p. 188.

20 Ibid. bd. 9, pp. 327-31.

21 Ibid., pp. 221-226.

22 DDS 247, v. 3. 